\title{
From Philosophia Naturalis to Science, from Latin to the Vernacular
}

\author{
H. Floris Cohen
}

\begin{abstract}
Immo si nauta descendit ad fundum maris ut habeat super humeros centum dolia aque ipse non sentit gravedinem illius aque quia illa aqua que est supra ipsum non inclinat ad amplius esse deorsum sed respectu aeris inclinaret si aer esset inferior. Et iterum quamvis aqua non esset in suo loco naturali sed multum alte in vase ut in cacumine turris beate marie tamen una pars respectu alterius non inclinaret ad esse deorsum ut si aliquis esset ibi in balneo et haberet tibiam suam in fundo ita quod supra eam esset magna quantitas aque quam ipse in aere non posset portare tamen non sentiret pondus illius aque. ${ }^{1}$
\end{abstract}

Even if a sailor descends to the bottom of the sea so that he has one hundred vessels of water upon his shoulders, he does not sense the weight of that water, as that water which is above him does not incline to be farther below. And even if the water were not in its natural place, but very high in a vessel like on top of the tower of the Notre Dame, still one part of it would not incline to be below so that, if someone would be there in a bath with his leg on the bottom so that above that leg there would be a large quantity of water which in the air he would not be able to carry, he would still not feel the weight of that water.

Sentences like these would not have pleased Cicero. They come neither from live Roman speech, nor from dead scholarly Renaissance speech, but from live medieval speech. They were spoken by a fourteenth-century teacher at

1 Buridanus, Subtilissime questiones super octo phisicorum libros Aristotelis, fol. 74rb-75ra; see also Toth, The Concept and Role of experimentum in John Buridan's Physics Commentary, p. 9o. Reprint of the edition Paris 1509 of the Subtilissimae quaestiones super octo Physicorum libros Aristotelis in 1964 as Kommentar zur Aristotelischen Physik. Grant, 'John Buridan, a Fourteenth Century Cartesian'; idem, 'Medieval Natural Philosophy: Empiricism without Observation'; King, 'Jean Buridan's Philosophy of Science'; Klima, John Buridan. 
the Paris Faculty of Arts, named Johannes Buridanus or Jean Buridan (c. 1300after 1358).

In speaking these lines Buridan was setting forth to his students an intriguing detail of Aristotelian natural philosophy as expounded in Book IV of Aristotle's treatise $\Phi v \sigma x \eta \dot{n}$. The treatise was not entitled thus in Buridan's handwritten copy, which was in Latin (as translated from Arabic) and carried the title 'Physica'. The customary translation 'Physics' suggests that this work shares much ground with the modern discipline of that name. This is far from the case. The point is not so much that modern physicists tend to regard Aristotle as a remarkably inept colleague in that he managed to have it wrong so often on truly fundamental topics like motion or the composition of matter. Rather, in this work (literally entitled 'On Nature') Aristotle was not in any way a scientist but rather a natural philosopher. Unlike a modern physicist he derived all conceivable phenomena in the whole natural world from certain first principles regarded as self-evidently true. To cultivate natural philosophy was a speculative business. A few empirical phenomena like falling objects or mixed fluids provided food for the formation of those first-principles, but for the rest the sole function of empirical phenomena was to illustrate and, in so doing, to underscore their indubitable truth.

Precisely that is what happens in the passage by Buridan just quoted. There is no question here of his finding out what may happen when a sailor descends to the bottom of the sea-does he feel the weight of the water pressing upon his shoulders, or does he not? Nor has Buridan really taken a bath-tub, carried it up the freshly laid, still snow-white stone steps of the Notre Dame, placed it on top of the tower, filled it with water taken upstairs by his teaching assistants, and seated himself in the bath so as now to find out for himself whether he feels the weight of all that water pressing upon his legs or not. The reason he does not bother to carry out these experiments is that he already knows the answer, which had been given by Aristotle, or rather-since Aristotle had not asked the question-could immediately be derived from Aristotle's first principles. These involve the idea of natural place-heaviness is the inclination of an object to move to its natural place, which for earthy matter is as near the centre of the universe as it can get, and for watery matter as near as it can get to the earthen sphere thus formed around that centre. Buridan does not give us here an early instance of experimentation, but rather fits in with the predominant mode of pursuing knowledge of nature in his time, which is through speculative thought sustained by pieces of empirical evidence. These are borrowed most often from everyday experience but on occasion, like here, from a pseudo-experimental setup. And all this is done in Latin. 
To the rule that, in medieval and also in Renaissance Europe, speculative natural philosophy was done in Latin there are, to my knowledge, few exceptions. One exception is a commentary on Aristotle's De caelo written by order of the French king by the most original of all medieval natural philosophers, Nicole Oresme (c. 1320/5-1382), under the title Le Livre du ciel et du monde ("The Book of Heaven and Earth'). ${ }^{2}$ This contains among many other things a sophisticated discussion of whether perhaps the stars stand still and the Earth turns around its own axis, but which in the end settles the argument with an appeal to Psalm 92:1: 'nientmoins touz tiennent et je cuide que [le ciel] est ainsi meu et la terre non: Deus enim firmavit orbem terre, qui non commovebitur' ('even so everybody maintains and I, too, think that the Heavens are moved and not the Earth: For God hath established the Earth, so that it shall not move'). ${ }^{3}$

On the whole, however, the vernacular was not so much the language of natural philosophy as rather of another mode of pursuing knowledge of nature, one that came up in Europe about half-way through the fifteenth century. This was an empiricist mode, not experimental as a rule but rather focused on finding out how things in nature actually behave and also how to make some practical usage of those findings. The properties of phenomena are not known beforehand, as in natural philosophy, but have actually to be traced down and accurately described first. For instance, Leonardo da Vinci (1452-1519) investigated in the Italian language but also in neat drawings how precisely birds manage to fly, with a view to having bird flight imitated by humans. In a similar vein Paracelsus (Theophrastus Bombastus von Hohenheim, 1493-1541) investigated properties of chemicals, which he used for the preparation of mineral cures, all in an often esoteric mixture of German and Latin phrases, like for instance: 'Das ding das zu eschen wirt, das ist ein Substantz, das ist ein stuck dorauß das holtz wirt. Und wiewohl es ist Ultima materia und nit prima, So beweist es aber primam materiam, deren Ultima sie ist [...].' ('the thing that turns to ash is a substance: a piece of that [stuff] of which wood is made. And even though it is ultima materia and not prima [materia], nevertheless it establishes the prima materia of which it is the ultima...'). ${ }^{4}$ Other empiricist

2 Modern edition in: Nicole Oresme, Le Livre du ciel et du monde, ed. Menut and Denomy. On Oresme, see also Taschow, Nicole Oresme und der Frühling der Moderne, and the review by Goddu; a biography by Kirschner in Zalta (ed.) Stanford Encyclopedia of Philosophy.

3 Oresme, Le Livre du ciel et du monde, ed. Menut and Denomy, p. 536; See also Molland, 'Nicole Oresme and Scientific Progress'.

4 Paracelsus, Opus Paramirum 1, 74; Paracelsus, Theophrastus Bombastus von Hohenheim, 1493-1541: Essential Theoretical Writings, ed. Weeks, p. 320. On Paracelsus, see, for instance, Webster, Paracelsus: Medicine, Magic and Mision at the End of Time. 
treatises are just in Latin, such as those of Andreas Vesalius (1514-1564) and Tycho Brahe (1546-1601), who reported in Latin on their findings regarding human anatomy and the exact placement in the heavens of the stars and the planets, respectively. In some cases the usage of the vernacular may look explicable in that there were close connections with the domain of the arts and crafts, as notably with Leonardo but also numerous others. Yet of Vesalius, who had his famous anatomical atlas De humani corporis fabrica (1543) illustrated by some of Titian's students, quite the same can be said. So a general rule for the choice made is hard to come by.

This strongly empiricist current in the pursuit of nature-knowledge did not go back to the Ancients. That is surely why the load of ancient tradition and ancient language was felt less heavily in these forward-looking pursuits than in natural philosophy, where ongoing exposition of ancient truths established long ago was the rule. This was also the case in a third mode of pursuing knowledge of nature, the mathematical variety. Recall the bath-tub Buridan fancied being taken up the Notre Dame, and also that in antiquity Archimedes (287-212 BC) had developed his own views on the weight of water inside a bath-tub-he allegedly jumped out of it and ran through the streets of Syracuse in the nude, exclaiming 'Eureka'! What he had found, was that the apparent loss of weight of his or any other body immersed in a fluid equals the weight of the fluid displaced thereby - a proven mathematical theorem quite at variance with Buridan's speculative a priori conviction that at least at certain places water in a bath-tub weighs nothing. Buridan still had no inkling of Archimedes' worknatural philosophy stemmed from the schools of Athens, mathematical science from Alexandria and subsidiary courts, and not until half-way through the seventeenth century did the twain actually begin to meet on a more than incidental scale. ${ }^{5}$

To the large extent that mathematical science was of Greek origin, it was mostly recovered in Europe during the Renaissance. The Greek texts, freshly imported from Byzantium after its conquest by the Ottomans in 1453, were reconstituted, translated, sometimes expanded, and most often also printed into Latin, by scholars lately dubbed 'mathematical humanists. ${ }^{6}$ Mathematical science dealt not only with what we now call pure mathematics, but also with planetary trajectories (Ptolemy), equilibrium conditions for solids and fluids (Archimedes), musical intervals, and light rays. Writing about these subjects was done as a rule in Latin, as for example in an effort by Nicolaus Copernicus

5 The statements here so baldly asserted are basic to Cohen, How Modern Science Came Into The World.

6 Rose, The Italian Renaissance of Mathematics. 
(1473-1543) to set Ptolemy's errors right and restore Greek planetary astronomy to its original purity, entitled De revolutionibus orbium coelestium ('On the Revolutions of the Heavenly Spheres', 1543). Still, in mathematical science, too, there is the exceptional treatise in the vernacular, as for example three treatises on musical theory in which the Venetian choir master Gioseffo Zarlino (1517-1590) sought to bring the Pythagorean account of musical consonance in line with recent developments in musical composition, as notably the usage by composers of the triad as the foundation of harmony. ${ }^{7}$ It is tempting to ascribe the use of the vernacular in Zarlino's case to his hopes of reaching an audience beyond the world of scholarship, yet a parallel treatise by the Spanish musical theorist Francisco de Salinas (1513-1590), De musica libri septem (1577) that must have aimed for a similar audience was written in Latin. ${ }^{8}$

Another exception is a kind of mathematics not known to the Greeks, which rather stems from India (decimal place system, invention of zero) and the Islamic world (algebra). Upon reception in Europe, the subject was almost always addressed in the vernacular, which need not surprise in view of the largely commercial usage to which these numbers and computations were as a rule being subjected. To the scholarly world properly speaking they hardly yet belonged.

On the whole, and barring exceptions that do not always look readily explicable, in Europe by the year 1600 there are three almost entirely separate modes of pursuit of knowledge of nature, to wit, highly abstract geometric science written in Latin; speculative natural philosophy also written in Latin, and fact-finding empiricist researches written in Latin or in the vernacular in very roughly equal measure. Natural philosophy predominates in all this, albeit no longer in the Aristotelian variety exclusively, as in Buridan's and Oresme's times. By far the majority of those engaged in the pursuit of nature-knowledge are philosophers, most often university professors who naturally deal in Latin, or Jesuit fathers who almost always wrote in Latin, too. For instance, of the Jesuit who persuaded his superiors to take some mathematics up in the order's regular philosophy courses, a German who invariably signed as Christophorus Clavius (1537/8-1612), we do not even know his real family name-Christoph Klau is just a guess. ${ }^{9}$

7 An online edition of the three works on TMI: http://euromusicology.cs.uu.nl/; a facsimile online edition of the Italian (1562) on: http://imgbase-scd-ulp.u-strasbg.fr/displayimage .php?album $=556 \&$ pos $=0$; translation of Le istitutioni harmoniche (1558) by Palisca.

8 Online edition on Thesaurus Musicarum Latinarum: http://www.chmtl.indiana.edu/tml/ start.html.

9 On Clavius, see Lattis, Between Copernicus and Galileo. 
With the year 1600 we have now reached the onset of the Scientific Revolution. It took shape as the near-simultaneous occurrence of three distinct revolutionary transformations. Each of the three modes of nature-knowledge just distinguished underwent certain drastic changes, and I shall now list the major works that together embody those changes, with a view to the language in which they were written. ${ }^{10}$

Mathematical science in the Greek mode was revolutionized by Johannes Kepler (1571-1630) and by Galileo Galilei (1564-1642). Kepler's publications are all in rather convoluted yet grammatically correct Latin, with the exception of a few prognostications he wrote in most charming German for his several employers, from Emperor Rudolf II to Count Wallenstein. Here, for instance, is Kepler's view on the worth of astrology, a view as skeptical as in the end it is confident:

Niemandt soll für ungläublich halten / daß auß der Astrologischen Narrheit und Gottlosigkeit / nicht auch eine nützliche Witz und Heiligthumb / auß einem unsaubern Schleim / nicht auch ein Schnecken / Müschle / Austern oder Aal zum Essen dienstlich / auß dem grossen Hauffen Raupengeschmeiß / nicht auch ein Seidenspinner / und endtlich auß einem übelriechenden Mist / nicht auch etwan von einer embsigen Hennen ein gutes Körnlin / ja ein Perlin oder Goldtkorn herfür gescharret / und gefunden werden köndte.

No one should consider it unbelievable that from astrological folly and impiety also useful wisdom and a sanctuary; from unclean slime also a snail, muscles, oysters, eel, serviceable as food; from the huge pile of vermin of caterpillars also a silk moth, and finally, that by an industrious hen from foul-smelling manure might be grubbed out and found a good grain of corn, nay, even a pearl or a grain of gold. ${ }^{11}$

There is little chance that Astronomy \& Astrophysics or any other learned journal anywhere in the world would still accept, or even be willing to have refereed, prose of such poetic beauty!

10 Cohen, How Modern Science Came Into The World (this book is one lengthy investigation into the question of what, if any, identifiable coherence can be seen to underlie the diverse events that together make up what may still with justice be called 'the Scientific Revolution of the seventeenth century').

11 Kepler, Gesammelte Werke, ed. Van Dyck a.o., vol. 4, p. 161 (from Tertius interveniens: Warnung an etliche Gegner der Astrologie, das Kind nicht mit dem Bade auszuschütten). 
In any case, Kepler generally used Latin. The case of the other revolutionary in mathematical science, his contemporary Galileo Galilei, is different-it looks as if his choice of Latin or the vernacular was determined by either the audience aimed at or the history of his own text. His first book publication, which contained his telescopic discoveries, was in Latin, Sidereus nuncius ('The Starry Messenger', 1610). ${ }^{12}$ Describing many new astronomical discoveries, and intended by its dedication to enhance the glory of Cosimo de'Medici, the book and accompanying telescopes were distributed all over Europe through the diplomatic network of the Grand-duke of Tuscany; therefore, Latin was the obvious choice. The various polemics in which Galileo got involved as his adherence to Copernicus' idea of an Earth moving became more outspoken, took place mostly in Italian, directed as they were at his home front. So was the book that provoked the infamous trial in which he set forth a plethora of arguments for Copernicus and against Aristotle and Ptolemy, the Dialogo sopra i due massimi sistemi del mondo, Tolemaico e Copernicano ('Dialogue on the Two Most Important World Systems, the Ptolemaic and the Copernican', 1632). This somewhat flawed yet path-breaking, brilliant, and immensely witty book was meant to win over an audience not skilled in any astronomical technicalities, hence for sure Galileo's opting for the vernacular. ${ }^{13}$ The Inquisition banned the book, yet within two years of the ban and of Galileo's condemnation a Protestant publisher in Straßburg issued a Latin translation, with other translations in other languages following soon.

Meanwhile the most revolutionary work of all, Galileo's Discorsi e dimostrazioni matematiche intorno ai due nuove scienze of 1638 , is in a sense bilingual. ${ }^{14}$ The earlier Dialogo presented itself as an ongoing conversation between three scholars, Galileo's mouthpiece Salviati, further Sagredo, the bright layman who anticipates the questions that might occur to an intelligent reader, and finally Simplicio, who caricatures the Aristotelian point of view. In the Discorsi the same threesome carries on the conversation, once again distributed over four Giornate or 'Days', only, on Day III of the Discorsi Salviati turns to reading aloud a lengthy Latin manuscript written by a person called 'Our Academician'. This of course is Galileo himself, who was a proud member of the 'Accademia dei Lincei'. The curious alternation of languages that follows, reflects the history

12 See http://www.rarebookroom.org/Control/galsid/index.html. The best book on Galileo's life and works is Heilbron, Galileo.

13 It was translated by Drake: Dialogue Concerning the Two Chief World Systems.

14 Online edition: http://www.liberliber.it/biblioteca/g/galilei/discorsi_e_dimostrazioni_ matematiche_intorno_a_due_nuove_etc/pdf/discor_p.pdf. The book has also been translated by Drake: Two New Sciences. 
of Galileo's own thought- the laws for perpendicular fall, for fall along an incline, and for projectile motion that fill Day III and IV of the Discorsi had all been discovered and written down in the 1590s, when Galileo was still a university professor at Padua. Accordingly, Latin seemed the most obvious language to write in even if only in private.

So, on the whole, the language in which mathematical science was written around 1600 continued to be Latin even though it was robbed of its extreme abstractness and placed in far closer contact with reality by means of Kepler's laws of planetary motion and Galileo's laws of falling and projected bodies. This was true, in spite of the special circumstances that moved Galileo in defence of his Copernicanism to appeal to a lay audience. The revolutionary works that at about the same time gave rise to a partly novel philosophy of nature present a somewhat more mixed picture. Isaac Beeckman (1588-1637), the first to enrich ancient atomism with a wholly speculative account of natural phenomena in terms of the various movements supposedly carried out by tiny particles in incessant motion, did so in his private notebook only. ${ }^{15}$ Sometimes the subject matter appeared to lend itself far better to one of the two languages at his disposal than to the other, as for instance with his notes on topics that concern engineering problems in the Netherlands. Even so, it is not always so easy to tell for what reasons he used now his somewhat stilted Latin, now Dutch. One given entry is almost always in one language only, yet even on a single day Beeckman might well alternate between the one and the other language. Given the nature of a diary, topics keep recurring forever, and although sometimes Beeckman appears to have a predilection for treating a given topic consistently in either Dutch or Latin, more often than not he chooses now the one now the other without any apparent rule or order.

His disciple and friend René Descartes (1596-1650) presents a complicated case in another sense. ${ }^{16}$ For instance, the first work that he wrote with a view to having it published carried a characteristically modest title, 'Le monde' ('The World'). News of Galileo's condemnation caused him at once to bury the nearfinished manuscript in his desk drawer. Not until he found a way to circumvent the attribution of motion to the Earth did he publish another text with basically the same content, this time in Latin, under the equally modest title Principia philosophiae (1644) — soon, under Descartes' own supervision, translated into French. French was also the language of his first publication, the Discours de la méthode (1637), which among other things provided a brief summary of

\footnotetext{
15 Van Berkel, Isaac Beeckman (1588-1637) and idem, Isaac Beeckman on Matter and Motion.

16 Good studies of his life and works are Gaukroger, Descartes: An Intellectual Biography and Clarke, Descartes: A Biography.
} 
some main points of 'Le monde'. The Discours is really an extensive preface to three appended treatises on mostly mathematical subjects, to wit, the rainbow and other atmospheric phenomena; the refraction of light in lenses, and a treatment of geometric curves and algebraic equations. The latter treatise, a highly advanced, truly pioneering work simply entitled La géométrie, did not begin to make a vast impact until a Latin translation appeared, which was later to serve young Isaac Newton (1642-1727) as his first introduction to mathematics-an incredible feat in its own right. Descartes was very much of an opportunist, and we need scarcely doubt that he thought hard and fast about the language most proper for each of his publications. His ultimate aim was to replace Aristotle as the predominant natural philosopher. Both his move to the Netherlands, where he lived for the largest part of his active life, and his ongoing cultivation of Jesuit priests were meant to serve this final objective, and it looks as if he made the choice between publication in Latin or in French subservient to it.

The third pioneer of a speculative natural philosophy of moving particles was Pierre Gassendi (1592-1655), who, however, never published in any other language than prolix Latin. ${ }^{17}$

The third revolutionary transformation concerns a much increased, more pointed usage of fact-finding experiments than happened earlier in the empiricist investigations of a Leonardo or a Vesalius. Francis Bacon (1561-1626) advocated this in a work meant to supplant Aristotle's Organon, hence appropriately entitled Novum organum (1620). It forms one part of an uncompleted work in which he hoped to put down his entire program for the wholesale upheaval of the pursuit of nature-knowledge, entitled Instauratio magna. The only work on the subject that he wrote in English is New Atlantis (1626), an utopian treatise depicting an ideal society run on the kind of applied science that Bacon envisaged. Three more pioneers of fact-finding experimentalism, who unlike Bacon also practiced what they preached, all published their most path-breaking or even all their works in Latin-William Gilbert's De magnete ('On the magnet', 160o), William Harvey's Exercitatio anatomica de motu cordis et sanguinis in animalibus ('Anatomical Exercise on the Motion of the Heart and Blood in Animals', 1626), and Jan Baptista van Helmont's Ortus medicinae ('The Dawn of Medicine', 1648). Only, the Ortus is a (vastly expanded) translation, prepared by van Helmont himself, of a text he first wrote in Dutch under the title Dageraet (likewise, in view of his running conflict with the Inquisition, published posthumously, this one in 1659). Van Helmont mentioned two

17 See Osler, Divine Will and the Mechanical Philosophy, and Fisher, Pierre Gassendi's Philosophy and Science. 
reasons for writing in his mother tongue. He wanted to be comprehensible to those closest to him (a consideration familiar to those who, like van Helmont, stood in Paracelsus' tradition). But it was also part of his personal epistemology that the ideas we receive are conceptualized by us in our mother tongue. Since van Helmont had picked up all his academic knowledge at Louvain university, in scholastic Latin, the writing of Dageraet faced him with the task of finding suitable Dutch equivalents for well-known Latin concepts, as also for concepts he thought up himself (for instance, he invented the idea, and also the term, 'gas', loosely derived from Greek 'chaos'). Even so, the grammatical structure the reader encounters in Dageraet leans heavily on the Latin way of sentence construction instilled in Joan Baptista as a youth. ${ }^{18}$

For the first generation that made the Scientific Revolution, then, Latin seems on the whole to be the preferred language to use. This is particularly curious in the case of the experimentalists, whose approach to natural phenomena is least marked by the ancient tradition - the vernacular used by Leonardo, Paracelsus, and many others working in an empiricist vein is not continued, with two prominent exceptions only, The New Atlantis and Dageraet. In mathematical science and in natural philosophy the picture looks more mixed. This is due above all to the presence of two authors very much concerned with their public image, Galileo and Descartes, who with regard to the most appropriate language to take appear to face a fresh decision every time a new publication is in the offing.

One major change that marks the transition to the next generation, roughly comprising those active between the 1650 s and the end of the seventeenth century, is the rise of scientific societies.

The pursuit of nature-knowledge had always been a highly patronageinfested affair. Whereas Aristotelian philosophers were entrenched in the universities or, if they were Jesuits, in the order of that name, mathematical scientists and fact-finding experimentalists depended for their living and for their chances to publish on an individual patron if they could find one. By the 166os patronage begins to change in kind, at least where the pursuit of natureknowledge is involved, insofar as it shifts from mostly individual to more institutionalized forms. Not counting the Jesuit order, three scientific societies come up, a fairly short-lived one in Florence and two highly important ones in Paris ('Académie Royale des Sciences') and in London ('Royal Society, for the improvement of naturall knowledge by Experiment'). Under its aegis the first

18 See http://www.dbnl.org/tekst/helmoogdageo1_01/. Many thanks to Sietske Fransen, who is preparing a $\mathrm{PhD}$ thesis on the subject, for all the information she kindly gave me about the existence and some intriguing features of Dageraet. 
scientific journal comes into being, the Philosophical Transactions (since 1665). The journal quickly develops a style of reporting of its own, directed above all to getting across a sense of the veracity of experimental events. Circumstantial, matter-of-fact, sober, down-to-earth reporting ought to vouch for the truth of the experimentally found facts reported upon. As a rule, the journal published in English.

One prominent Fellow faithfully to follow and to expound this kind of reporting of experimental findings was the Anglo/Irish investigator Robert Boyle (1627-1691). ${ }^{19} \mathrm{He}$ encountered the very same problem that had exercised Jean Buridan three centuries earlier, albeit in a radically altered context. Concerned with Aristotle's doctrine of natural place, Buridan had come to argue that a sailor on the bottom of the sea does not feel the water pressing upon him. Boyle came upon the same issue through his experiments with the air pump. Unlike Buridan, Boyle questioned numerous people who, albeit not divers themselves, had heard actual divers report that, generally speaking, they did not experience a crushing weight at the depths they were able to reach. The problem that remained for Boyle was the reliability of these testimonies: could one really trust a person of the low social status of a professional diver? All this, to be sure, went on in English, which by now was the regular language in which to report on experimental matters. Still, the Royal Society aimed to serve, not only the sake of experimental science in Great Britain, but also on the Continent. Hence, foreigners need not publish in English but might contribute in Latin as well. Only in the case of Antonie van Leeuwenhoek (1632-1723), who had no other language than Dutch, the letters to the Royal Society in which over many decades he wrote down his microscopic discoveries had to be translated into English, not Latin, first.

Generally speaking, then, and with the Jesuits' Latin definitely a case apart, the vernacular tended to get settled as the language in which to report on experiments, and Latin to remain the lingua franca in mathematical science. However, after mid-century two pioneers, Isaac Newton and Christiaan Huygens, began to blend these categories, as notably in their optical work. It is informative to follow Newton's choice of language throughout his publishing career, particularly where his writings on light and colour are concerned. The private notes in which around 1665 he recorded his major discovery that sunlight is not pure white light but really a compound of all colours of the spectrum, plus the mostly experimental investigations by means of which he sought to clinch this conclusion, are all in English. Four years later he addressed his absent students on the subject in Latin. When in 1672 he broke his silence

19 See, for instance, Hunter, Boyle: Between God and Science. 
and informed the Royal Society of his discovery, he clad his 'New theory' in the prescribed format of the Philosophical Transactions. When this first publication of his involved him in an ongoing range of criticisms and rebuttals that he came to resent ever more deeply, he responded in Latin to one Jesuit critic on the Continent who neither knew English nor operated through the intermediary of the journal's editor, and for the rest in English. In the meantime he wrote, also in English, an extensive experimental account of numerous optical phenomena for the benefit of the Royal Society, not to be published but only to be read aloud over many consecutive sessions. Still, he kept seeking a mathematical foundation for his theory of colour, yet in the end in vain. So when by the 1690 s he collected all his optical material for a publication in book form, he had two reasons for writing it in the vernacular. Due to the missing mathematical foundation his account had to be focused primarily on the sustaining experimental evidence. Also, decades earlier he had already produced many serviceable texts in English. That is how he came to write in that language his second book, under the succinct title Opticks (1704). A Latin translation, supervised and supplemented by Newton himself, appeared within two years.

Newton's first book however, which is on orbital motion and contains his discovery and proof of universal gravitation, was in Latin from the outset. It is entitled Philosophiae naturalis principia mathematica (1687), and it was not translated into English during Newton's lifetime. On the subject of motion treated the mathematical way Newton almost invariably wrote in Latin. One exception occurred when in 1679 a brief correspondence with Robert Hooke challenged him to derive the elliptical orbit of the planets from the supposition that some attractive force diminishing with the square of the distance deflects a planet from its rectilinear, uniformly traversed path. Newton cut off the correspondence, but he noted down the proof in English - possibly a reflection of the correspondence, which of course was in English. Five years later a visitor, Edmond Halley, learned from Newton that he had sought to prove that proposition, and asked Newton to show him the proof, which Newton then claimed not to be able to find back in his desk drawer. This time Newton wrote the proof down in Latin, and stuck to that language all through his subsequent journey of discovery which within three more years produced the Principia.

With Christiaan Huygens (1629-1695) a similarly mixed pattern can be found. His unequivocally mathematical masterpiece of 1673 is squarely in Latin-Horologium oscillatorium ('Pendulum Clock'). But with his optical researches he got himself into difficulties. When in the 1650 s he started a treatise Dioptrica on the refraction of light in lenses, with a view to optimizing telescopes, Latin was the obvious choice to make for so clearly mathematical a subject. But as he moved on, the problem of the nature of light began to 
captivate him. Originally a problem in speculative natural philosophy only, in Huygens' hands the question of what light really is got enveloped in a blend of mathematical reasoning and experimental testing, most of which he did in French. ${ }^{20}$ In 1679 he gave a lecture to his fellow Académiciens in French, which in 1690 he published as Traité de la lumière ('Treatise on Light'). His original treatise Dioptrica, on which he had kept working, remained unpublished during his lifetime. Language was in part responsible, witness the following apology in the preface to Traité de la lumière:

On pourra demander pourquoy j'ay tant tardé à mettre au jour cet Ouvrage. La raison est que je l'avois escrit assez negligemment en la Langue où on le voit, avec intention de le traduire en Latin, faisant ainsi pour avoir plus d'attention aux choses. Apres quoy je me proposois de le donner ensemble avec un autre Traité de Dioptrique, ou j'explique les effets des Telescopes, et ce qui apartient de plus à cette Science. Mais le plaisir de la nouveauté ayant cessé, j'ay differé de temps à autre d'executer ce dessein $[\ldots]$.

One may ask why I have delayed for so long the publication of this work. The reason is that I had written it rather negligently in the language in which one sees it, with the intention to translate it into Latin, doing so in order to give more attention to things. Next I planned to give it together with another Treatise on Dioptrics, in which I explain the effects of Telescopes, and all the other things that pertain to that science. But the pleasure of the new ceased, and I kept postponing the execution of that $\operatorname{plan} . .{ }^{21}$

Indeed, Huygens did translate a few pages of the Traité de la lumière in Latin, but apparently he got bored and gave up the effort, to the detriment of his treatise on the geometric properties of light rays refracting in lenses.

Newton had only Latin and English to choose from, but Huygens was after all a Dutchman, so he had three options. He wrote three treatises in Dutch. Two are manuals with detailed instructions for artisans-one for lense grinders, the other for mariners. ${ }^{22}$ The third is a foray in quite unknown territory-an utterly unGreek piece of mathematics dealing with probability calculus, which

\footnotetext{
20 Dijksterhuis, Lenses and Waves.

21 Huygens, Traité de la lumière, p. ${ }^{*} 2 \mathrm{v}$.

22 The treatises were, respectively, Memorien aengaende het slijpen van glasen tot verrekijckers ('Memoirs concerning the grinding of glass for telescopes', 1685) and Kort onderwijs
} 
he first wrote under the title Tractaet handelende van reeckening in speelen van gheluck (166o; 'On Reasoning in Games of Chance'), but with his Latin translation (De ratiociniis in ludo aleae) appearing three years earlier.

These somewhat scattered remarks allow no more than a provisional conclusion, suggested only by my reading over the years without ever making specialized inquiries into the subject of language in science. Barring the numerous exceptions and half-way cases that we have encountered along the way, that conclusion looks roughly as follows. On the eve of the Scientific Revolution, c. 1600 , Latin is standard in mathematical science. So it is in natural philosophy, which is invariably of the speculative kind. Empiricist investigations may be in Latin or in the vernacular, for reasons sometimes easy to detect, sometimes hard to guess. A century later, by the end of the 17th century, Latin is still standard in mathematical science insofar as the mathematics in question has recognizably Greek roots. Empiricist undertakings, now mostly experimental, are rendered most often in the vernacular, with for main exception Jesuit writings on the subject. Insofar as natural philosophy is still of a speculative kind, its cultivation is confined to the universities, with Latin as its obvious vehicle. But pioneers like Huygens and Newton seek to make natural philosophy hypothetical rather than speculative, and are blending it with experimentation and with mathematical argument, leaving the choice of language more a matter of convention or of pure coincidence. Indeed, the title of Newton's masterpiece, Philosophiae naturalis principia mathematica, while exemplifying the new blend, still bows to the old expression, natural philosophy, which by now translates far better into what it has really become in the meantime-science. Modern scientists have a hard time grasping what Aristotle or Buridan or even Descartes was up to, but Newton they rightly recognize as their older colleague, talking about the same things in basically the same manner as they do, albeit in a long superseded mathematical vocabulary. Natural philosophy had definitely given way to 'recognizably modern science.' ${ }^{23}$

On the whole, then, there is in the course of the seventeenth century a shift from Latin to the vernacular, but the shift is neither straightforward nor complete nor devoid of elements of the contingent and the coincidental. Did the shift continue? On the long run, certainly. When around 1800 the still largely separate domains of mathematical and empirical/experimental science began to fuse for good, this spelled by and large the end of Latin as a language

aengaende het gebruijck der horologiën tot het vinden der lenghten van Oost en West ('Short instruction concerning the use of clocks for finding longitude in East and West', 1686).

23 Drake used the expression (most often in the variety 'recognizably modern physics') in many of his works, e.g., on p. 98 of his Galileo: Pioneer Scientist. 
of science-excepting only Hans Christian Ørsted's discovery of electromagnetic interaction ('Circa efficaciam conflictus electrici in acum magneticam', 1820), not a single major nineteenth-century scientific discovery was still published in Latin. But in between, over the period of the Enlightenment, my overall impression is that things remained roughly in the state attained c. 1700, or even that Latin temporarily managed to regain some of the territory lost.

Still, the language of the classics left its stamp on the language of science for good. In what went before I have repeatedly spoken of mathematics, of experiments, of natural philosophy, etcetera-all expressions adopted straightforwardly from Greek or Latin. If I had written the present chapter in my mother tongue, I would not have used so many expressions of so unambiguously classic an origin. I would have spoken, not of 'mathematics' from Greek $\mu \alpha \dot{\theta} \eta \mu \alpha$, but of 'wiskunde', compounded from Dutch 'wis' = 'certain' and 'kunde' = 'expert knowledge'. Why is it that Dutch is so exceptional in having for 'mathematica' 'wiskunde', for 'proportio' 'evenredigheid', for 'parallel' 'evenwijdig'?

These, and many more words along these lines, we owe to one particular mathematical scientist of Dutch descent, Simon Stevin. ${ }^{24}$ Born in Brugge (Bruges) in 1548, he moved to the Northern Netherlands when he was about 30 years old. For many years he served Stadtholder Prince Maurits, until his own death in 1620. Of his many works, he wrote and published one in Latin, one in French, and all others in Dutch. As he kept writing in the vernacular, he turned ever more purist, to the point of inventing ever more Dutch words for expressing concepts available so far in Greek or Latin only.

He defended the practice in a piece entitled Uytspraeck van de weerdicheyt derDuytsche tael ('Discourse on the dignity and worth of the Dutch language'),, 25 in which he argued that Dutch lends itself more readily to scientific objectives than any other language. His most original argument runs as follows. In Dutch more than in any other language, Greek definitely included and Latin even more so, one can with great facility make composite words, which is an important feat 'since the names of things are also thereby their brief definitions' ('overmidts der dinghen namen daer duer oock hare corte bepalinghen sijn'). 'Evenwijdig' for 'parallel' indicates already by way of the expression itself that the width ('wijdte') is equal ('even'). 'Stelkunde' for algebra already indicates that this is the discipline which provides expert knowledge ('kunde') of what we 'stellen' = suppose. And so on. In the end Stevin even went so far as to argue that very long ago, in the 'Wijsentijt' (Age of the Sages) when all the knowledge

24 There is a recent biography: Devreese and Vanden Berghe, Magic is no Magic.

25 It is Stevin's own prologue to his De Bheginselen der Weeghconst ('Principles of Statics'). 
was already available which the present age is busily seeking to recover, the one and only language spoken was Dutch-really humanity's Ursprache!

All this went beyond sheer terminology. Indeed, Stevin's purist predilection for the vernacular and the properties he rightly or wrongly attributed to it helped decide the course of arguments he made in mathematical science. Here, to conclude my argument, is one extended example. One of Stevin's treatises is entitled 'Vande Spiegheling der Singconst' — a typically purist title. 'Vande' just means 'On the.' 'Spiegheling' stands for 'theory', attained along the following route: Dutch 'spiegel' is mirror; light rays reaching a mirror reflect, hence 'spiegeling' = 'reflection', which is quite near 'theory'. 'Singconst' is literally 'the art of singing', which is how Stevin renders the term music ('muziek' in Dutch). So the title as a whole translates as 'On the Theory of Music'. In it he defends a quite original thesis. You may know that modern musicians, notably pianists, play in equal temperament. That is, the tuner has divided the octave between $\mathrm{C}$ and the next higher $\mathrm{c}$ in 12 semitones of equal size, so that there is no difference between, say, D sharp and E flat. This, to be sure, is an artificial arrangement. Musicians unencumbered by a keyboard instrument, notably singers, do make a difference between these semitones, and generally seek to get as many consonant intervals as pure as they can. That is, they seek for the major third that is given by the frequency ratio $5: 4$, for the fifth as $3: 2$, and so on. The whole problem is that to have all consonant intervals pure is strictly impossible; a compromise has to be struck, and after three centuries of bickering over the best temperament the arrival on the scene of the piano finally decided in favor of the most deadening of all possible temperaments, the great equalizer, equal temperament. What is original in Stevin's treatise is that he regarded this artificial manner of resolving an inevitable problem not as artificial at all, or indeed as a problem in need of solution, but rather as the natural tuning system. It is not the ratio 5:4 that defines the major third, but the cube root of 2 does. Not artifice but nature itself thus divides the octave, or so Stevin stubbornly upheld over the length and breadth of his treatise.

He adduced numerous ingenious arguments to support this outrageous thesis, and one is derived from language. It runs like this. How is it that the Greeks, who were clever enough to hit upon the true, equal division of the octave, came up instead with this childish division according to these ratios of the first few integral numbers like 2:3 or 3:4 or 4:5? Why did it require a Dutchman to find out that all the consonant intervals flow from the equal division of the octave into twelve semitones? Here is why. The Greeks should have derived the division from the only proper kind of proportionality, geometric proportionality, which unlike so-called arithmetic or harmonic proportionality leads at once to the equal division. But they failed to recognize this. Neither the Greek 
nor the Latin words express the relationship between the ratios of the terms in question. Greek has $\lambda o^{\prime} \gamma \circ$ for 'ratio', and $\alpha \nu \alpha \lambda$ oria for their relationship. Latin, along with all the languages that stem from it, is even worse: it provides no connection at all between ratio and proportio. But luckily there is one language which can express the connection quite clearly and concisely. This language is Dutch, and the proper word for it has been coined by Stevin himself-evenredigheid. This, Stevin says, is a word "of infinite power", for it is the "definition of its own essence":26

...te seggen dat 6, 4, 3 en dierghelycke Singconstighe everedenheyt maecken daer oneindelycke ydelheden uijt volghen ende besloten worden; Men antwoort duer beweghing van tvoornoemde gheluijt, hier van syn gheen even Rhedens, daerom oock gheen Everedenheyt.

Or, translated in the language of this book, however unfit to make this particular point since all terms in question derive straightforwardly from the very Latin Stevin deemed unfit for scientific discourse:

... from the statement that $6,4,3$ and the like constitute a harmonic proportion ('everedenheijt'), an infinite series of vanities follows and is made to follow. One responds by pronouncing the aforesaid word: here are no even Ratios, therefore, there is no Everedenheyt.

Language, then, is more than a neutral vehicle for scientific arguments; on occasion it can influence them, alter them, or, as here with Stevin, even go so far as to appear to decide them.

26 Cohen, Quantifying Music, pp. 57-61. 